\title{
PUBLIC INTEREST AS A POSITIVE CONDITION OF APPLYING RELIEFS IN PAYMENT OF NON-TAX PUBLIC LAW LIABILITIES TO STATE
}

\author{
ZBIGNIEW OFIARSKI
}

\begin{abstract}
The subject of this work is the analysis and assessment of applicable legislation concerning the application of reliefs in payment of non-tax liabilities to state, in particular, the condition of "public interest" which justifies such a relief. The works confirm the need to use general clauses including, most of all, the "public interest" clause, which considers universal and generally acceptable values (e.g. justice, safety, equal treatment, building trust in public administration bodies). It is not defined in any act; therefore, it is vague. Using the dogmatic legal method, the normative material, as well as the achievements of the doctrine, have been examined; court rulings have been examined using the empirical method. That enabled the Author to show that public interest is one of two equivalent and disjunctive conditions justifying application of a relief in payment of non-tax liabilities to state. The important interest of the debtor may be the second condition. The fact that any of those conditions is met entitles a competent authority to apply one of the following reliefs in payment: deferred payment date, payment in installments, or remittal of a liability. In each case, the relief may pertain to a part of or the whole liability. It should be assessed in the context of a specific case.
\end{abstract}

\section{Keywords}

State budget; reliefs in payment; public interest; non-tax liabilities to state

\section{JEL Classification: H2, H3, H61}

1 Professor of Finance Law, Head of the Department of Finance Law, Faculty of Law and Administration, University of Szczecin, Poland. The Author of over 550 publications, including 38 books (monographs, students books, and commentaries), articles, studies in joint works, and electronic publications. Specialises in tax law, local government finance law, and banking law. He is a member of Information and Organization Centre for the Research on the Public Finances and Tax Law in the Countries of Central and Eastern Europe. Contact email: zbigniew.ofiarski@usz.edu.pl. 


\section{Introduction}

The purpose of this work is to analyze and assess applicable legislation concerning the application of reliefs in payment of non-tax liabilities to state, in particular, the condition of "public interest" which justifies such reliefs. The legislation in this area is not perfect, as no universal and legal definition of "non-tax liabilities to state" has been formulated, which would not raise doubts as to interpretation, and the condition of "public interest" is a typical general clause used by the legislator. The function of a general clause is an order to modify specific central regulations (i.e. regulations which are within the scope of interest due to their substance), directed at the entity applying the law. This modification results in considering opinions functioning in the society in the process of applying specific regulations (Zieliński, 2002: 126). General clauses are one of the basic ways to make law flexible by referring to a specific system of values and opinions justified in an axiological manner (Wronkowska, Zieliński, 1993: 110).

In public finance law, general clauses (referring to justice, equality, universality, social solidarity, or budget balance) introduce a specific freedom of decision (Münnich, 2013: 149) in solving, by public authorities, specific cases related to creating and distributing public financial resources. Therefore, they ensure flexibility of action depending on changing the political, economic, and legal environment, with no need of introducing frequent changes in legal regulations containing orders or prohibitions (Małecki, 2005: 463).

The issue of applying for reliefs in payment of such liabilities is important from the viewpoint of the current state budget balance as well as its closing balance as at the end of the budget year. What decides about it, most of all is allowable types of reliefs (payment date deferment, payment in installments, and remittal of a part of or the whole liability) as well as the frequency of using them in a budget year in question. Economic consequences of using a specific relief may be short-term and may consist only in a later date of paying a specific amount to the treasury (payment date deferment or payment in installments); they may also be definitive and lead to a reduction of budget receipts (remittal of liability).

Reliefs in payment of non-tax liabilities to the state are important instruments of fiscal policy, which enable flexible reaction of entities collecting budget receipts to needs resulting from a specific situation of an entity obliged to pay such a liability. Reliefs in payment of non-tax liabilities to the state may create a risk of a temporary or definitive disturbance of budget balance; however, if they are not used and the liabilities are strictly enforced from the obliged entity, this may lead to a destruction of a specific source of budget receipts (Ofiarski, 2015: 205). 
Public Interest as a Positive Condition of Applying Reliefs in Payment...

The analysis and assessment of the applicable legislation are supposed to verify the hypothesis that the legislator refers to the general clause of "public interest" in the procedure of using reliefs in payment of non-tax liabilities to state with awareness. The public interest is a vague expression and, at the same time, a directive to respect values common for the whole society, such as justice, security, citizens' trust in public authorities, efficient operation of public administration, and possible correction of its wrong decisions (Gomułowicz, Skoczylas, 2013: 122). Using the premise of "public interest" enables competent authorities to act flexibly when making decisions on applying or refusing to apply for a specific relief in payment of non-tax liabilities to state. However, freedom of such authorities' action must not be complete, as the decisions should respect the universal values referred to above, related to the meaning of public interest.

In this work, the dogmatic legal method (examination of the normative material and the achievements of the doctrine), as well as the empirical methods (examination of court rulings), were used. Firstly, it has been determined that "public interest", which is a positive condition of using a specific relief in payment of non-tax liabilities to state, may form an independent basis for a decision made by a competent authority. That means, that in a specific situation it is not necessary to seek an important debtor's interest as well, as those conditions do not compete with each other. Each of them, separately, may result in a positive (the condition is met) or negative (at least one of the conditions is not met) decision in a case concerning a relief in payment of non-tax liabilities to state.

When examining the issue of using the condition of public interest as a general clause which enables flexible application of statutory regulations concerning reliefs in payment of non-tax liabilities to state, the current achievements of the tax law doctrine concerning payment of tax liabilities were also referred to. Due to certain similarities of legal solutions, those achievements have been found useful in the analysis of regulations concerning non-tax liabilities to state.

\section{Essence and Types of Non-tax Liabilities to State}

The expression "non-tax liabilities to state" is used, most of all, in the Public Finance Act (further: PFA) and the Tax Ordinance Act of 29 August 1997 (further: TOA). In those two acts, the legislator made an attempt at defining the essence of non-tax liabilities to state, listing their main types and even defining them. Art. 60 of PFA lists, in the form of an open catalog, main types of public law non-tax liabilities to state. That catalog is open, as Art. 60 of PFA uses the expression of "including without limitation to", which precedes the list of the most typical liabilities classified into this category. Therefore, the legislator allows a possibility 
of treating other public funds, which were not listed in that regulation directly, as non-tax public liabilities to the state.

Depending on which budget or special state fund the receipts from those sources are supposed to be paid to, they may be divided into three main groups, i.e. those paid to the state budget, those paid to local government budgets, or those paid to special state funds. With a more detailed classification, one may distinguish between nontax liabilities to state which are paid to commune/municipality budgets, poviat budgets, and voivodeship budgets as well as specific special state funds. Non-tax liabilities to the state budget, listed in Art. 60 of PFA, include:

- subsidies to be repaid in events defined in the relevant act;

- liabilities on guarantees and sureties granted by the Treasury;

- the surplus of funds paid by executive agencies;

- payments related to settlements of pre-accession programmes;

- liabilities on repayment of funds allocated to the realization of programmes co-financed by the EU and other liabilities related to the realization of such programmes, including interest on EU funds provided and on those liabilities;

- liabilities on fines imposed by way of a criminal penalty in the proceedings concerning transgressions and proceedings concerning fiscal transgressions;

- income collected by administrative units under separate acts.

Pursuant to Art. 3/8 of TOA, non-tax liabilities to the state are liabilities which are receipts of the state or local government budgets, resulting from public law relationships, excluding taxes and charges. That means that non-tax liabilities to the state have been put in opposition to taxes and charges and are, in consequence, a separate consideration (Huchla, 2014: 258). As a result of Art. 3/8 of TOA, regulations of that Act may be applied to a specific liability to state if it results from public law relationships, which should be understood as an existence of a certain relation between at least two entities, an existence of certain rights and obligations, resulting from specific legal provisions (these may include payments out of profit made by one-man state-owned companies to the state budget (Jamroży, Główka, 2017: 55). "Non-tax public law liabilities" understood in that manner mean liabilities which are a manner of following legal regulations rather than violating them (Supreme Administrative Court: II GSK 1693/13).

From that viewpoint, the status of administrative fines imposed by public administration bodies by way of administrative decisions is being discussed. In general, administrative courts recognize such fines as non-tax public law liabilities (e.g. Supreme Administrative Court: II GSK 1020/10; Supreme Administrative 
Public Interest as a Positive Condition of Applying Reliefs in Payment...

Court: I FPS 2/09; Voivodeship Administrative Court: II SA/Sz 1356/13). Such decisions are verified in administrative proceedings and are subject to control by administrative courts. Furthermore, fines imposed by public administration bodies are subject to administrative enforcement (Act on enforcement proceedings in administration). Administrative fines are also recognized as "non-tax liabilities to state" by some representatives of the doctrine (Drwiłło, 2010: 924; Ślifirczyk, 2007: 347). However, there are also different opinions in the literature, which state that the category referred to above should only include liabilities which are a manner of following legal regulations rather than violating them. As a result, the representatives of that trend do not recognize fines as "non-tax liabilities to state" (e.g. Popławski, 2017: 72; Borodo, 2009: 133).

The polemics concerning the status of fines may be influenced by the provisions of Art. 111/12 of PFA, which state that "other fines" are recognized as "non-tax receipts to state budget" unless other acts state otherwise. Art. 60 of TOA does not mention fines at all; however, as has been mentioned above, the catalog of non-state liabilities to state is open. Here, another issue arises, i.e. Art. 60 of PFA uses the expression of "non-tax liabilities to state", while Art. 111 of PFA mentions "nontax budget receipts". The notions of "liability" and "receipts" are not equivalent; furthermore, they are used by a legislator in different contexts. In Art. 60 of PFA, a liability should be understood as an obligation which already exists and which should be fulfilled by a specific entity by making a payment to the state. In Art. 111 of PFA in conjunction with Art. 110 of PFA, the notion of "receipts" should be understood as a source of receipts, from which incoming payments are made to the budget. Such a source is allocated to the budget; however, it is possible that a specific obligation of payment (amount, entity, payment date) does not exist at the moment concerned.

It should be underlined that administrative courts recognize, as "non-tax liabilities to state", even those liabilities which have been explicitly named charges by the legislator. That issue pertains, in particular, to charges collected for issuing a vehicle history card (Voivodeship Administrative Court: III SA/Kr 574/16; Voivodeship Administrative Court: III SA/Po 1263/13; Voivodeship Administrative Court: III SA/Po 535/13; Voivodeship Administrative Court: III SA/Ld 117/12). Pursuant to Art. 77 of the Road Traffic Act, a vehicle history card for a car other than a new car is issued by the poviat governor (pl. starosta) competent for registration, for a charge and after a payment of a registration charge, upon the first registration of a vehicle in Poland, except for historical vehicles. A duplicate vehicle history card is issued by the competent poviat governor for a charge and after a payment of a registration charge. 
The notion of "non-tax liabilities to state" is also used in Art. $22 \mathrm{~b}$ of the Act of 3 February 1995 on the protection of agricultural lands and forests. A list of such liabilities has been defined but only for the purposes of applying the provisions of that Act. Within the meaning of the Act concerning the protection of agricultural lands and forests, non-tax liabilities to state include voivodeship budget receipts related to excluding agricultural lands from production, which are collected under that Act in the form of various taxes or charges. The list includes liabilities, annual charges, charges for a failure to fulfill the obligation to remove and use the soil humus, charges, and liabilities, and increased annual charges for a failure to fulfill the obligations specified in the Act as well as interest on the liabilities and charges referred above. At the same time, it has been stated explicitly that the receipts referred to above are public law non-tax liabilities to state as understood in the Public Finance Act. With regard to those receipts, the voivodeship governor (pl. marszatek województwa) is a creditor Authorized to apply for reliefs in payment thereof (in the form of remittal, payment in installments, or payment date deferment (Brzezicki, Fisz, 2013: 40) as well as an authority enforcing liabilities on that account. The public law nature of those liabilities justifies the right of claiming the interest in the case of delayed payments, calculated as in the case of tax arrears (Góreczna, Góreczny, 2014: 54).

The notion of "non-tax liabilities to state" is also used in other legal acts; however, its essence or characteristics are not specified in detail. It is present as a component of exemption from various liabilities granted to prison workshops (Art. 6 concerning employment of prisoners) or as a part of a registration and identification obligation referring to entities using a NIP tax id. number (those entities are obliged to provide the NIP no. in documents related to fulfilling obligations on account of non-tax liabilities to state (Art. 11 of the Act on principles of registration and identification of taxpayers and tax remitters). Collection of receipts on account of non-tax liabilities to state is listed in the catalogue of responsibilities of the Polish Fiscal Administration and some of its bodies (Strzelec, 2017: 29), e.g. heads of tax offices and heads of customs and tax offices (Arts. 2, 11, 28, and 33 of the Act concerning National Fiscal Administration).

\section{Forms of Reliefs in Payment of Non-tax Liabilities to State}

Art. 64 of PFA specifies types of reliefs in payment and conditions of applying them with reference to public law non-tax liabilities to state. Reliefs in payment may come in the form of liability remittal, payment date deferment, or payment in installments. In each case, the relief may pertain to a part of or the whole non-tax liability to the state. The legislator has not introduced any restrictions concerning the 
minimum or maximum value of a non-tax liability to state which may be remitted, divided into installments, or paid by a deferred date. The application of a specific relief in payment brings various economic (temporary or permanent) effects. A temporary effect consists only in a later payment of a part of or the whole liability to the state and is related to payment date deferment or payment in installments. In case of applying the relief consisting in remitting (a part of or the whole) liability, the effect is permanent and it involves no receipt of a specific amount by state, one which would have been paid had it not been remitted. Budget receipts reduced in that manner have to be compensated with appropriately increased receipts from other income sources. In case of remittals of large amounts, it is often necessary to use debt instruments, such as bank loans, loans, or issue of Treasury securities; however, in such a situation the borrowed amounts have to be repaid with interest in the following budget years. Therefore, remittals will involve a need for additional spending by the state.

Reliefs in payment of public law non-tax liabilities to the state may be applied by competent authorities representing interests of the state. The expression of "competent authority may" used in Art. 64/1 of the PFA means that an authority is not obliged to apply for a specific relief in payment even if the conditions specified in that provision are met. Granting a relief in payment is a discretionary decision of the competent authority (Kucia-Guściora, 2014: 481). The decision made in such a case is discretionary, however, that does not mean that the authority is completely free to act in any way. On principle, administrative discretion means a possibility to choose, by an authority, a legal consequence in a specific legal and actual situation. In other words, when making a decision using administrative discretion, an authority makes a decision freely, and the final choice concerning the decision should depend on the usefulness and equity; those conditions should be the result of balancing, by the authority, the interest of a party and the public interest, considering applicable legal regulations (Supreme Administration Court: II GSK 2084/12).

Art. 64 of PFA lists several positive conditions of granting, at the obliged party's request, a relief in payment of non-tax liabilities to state. They include an important interest of the obliged party, public interest, social reasons, economic reasons, and payment potential of the obliged party. These are non-specific expressions (general clauses) which refer to certain general socially acceptable values (MalarewiczJakubów, 2014: 145-153). If any condition listed in Art. 64 of PFA is not met, the authority is unable to make a decision concerning the application of a specific relief in payment of non-tax liability to the state. However, it should be emphasized that not all of those conditions are bound, by the legislator, to each of reliefs in payment of non-tax liabilities to state referred to above. 
Public interest and important interest of the obliged party are conditions of remitting whole non-tax liabilities to state. Remitting whole liabilities should be understood as remitting a principal amount as well as accessory liabilities, which usually include interest for delay. Applying reliefs consisting in remittal of a part of a liability, deferment of the payment date of a part of or the whole liability, or payment of a part of or the whole liability in installments is allowable when justified for social or economic reasons, in particular in reference to payment potential of the obliged party.

\section{Authorities Competent for Remittal of Non-tax Liabilities to State}

A diverse catalog of non-tax liabilities to the state has determined the manner of regulating functional and material competences of authorities competent to apply for reliefs in payment of those liabilities, including to remit them. The competences of the authorities are regulated under Art. 61 of PFA. Pursuant to that regulations, authorities of the first instance competent to issue decisions concerning reliefs in payment of non-tax liabilities to the state are a minister, a voivode, other bodies entitled to dispose of budget components, and other managers of state administrative entities. In reference to liabilities from fines imposed by way of a criminal penalty in proceedings concerning transgression and in proceedings concerning fiscal transgressions, authorities of the first instance competent to apply for reliefs in payment of such fines are heads of tax offices.

In case of liabilities related to return of funds allocated for realization of programmes co-financed by the EU and other liabilities related to projects financed in that manner as well as interest on funds granted by the EU and the liabilities, competent authorities include management institutions, the entity responsible for implementing the Connecting Europe Facility, the entity performing the function of a National Contact Point or a National Coordinating Institution, respectively, in programmes financed with funds being aid provided by member states of the European Free Trade Association (EFTA) as well as units of the public finance sector being programme operators, intermediary institutions, and implementing institutions which made a subsidy agreement with a beneficiary if they are duly Authorised by a management institution, the entity responsible for implementing the Connecting Europe Facility, or the entity performing the function of a National Contact Point or a National Coordinating Institution respectively. Appeal authorities include:

a) the Minister of Finance (appeals against decisions issued by a voivode as a first instance authority), 
b) the entity performing the function of a management institution, the entity responsible for implementing the Connecting Europe Facility, or the entity performing the function of a National Contact Point or a National Coordinating Institution respectively (appeals against decisions issued by units of the public finance sector being programme operators, intermediary institutions, and implementing institutions which made a subsidy agreement with a beneficiary),

c) the entity performing the function of an intermediary institution (against decisions issued by implementing institutions if examining appeals against decisions issued by implementing institutions has been entrusted to the intermediary institution by the entity referred to in item b) above),

- director of a fiscal administration chamber (appeals against decisions issued by a head of a tax office as an authority first instance);

- a superior entity (appeals against decisions issued by other entities or other units entitled to dispose of a budget component).

Decisions issued by a minister, a management institution, the entity responsible for implementing the Connecting Europe Facility, and the body performing the function of a National Contact Point or a National Coordinating Institution respectively may not be appealed against; however, a party unsatisfied with a decision may request that the authority which issued the decision to re-examine the case.

Provisions of the Public Finance Act regulate only the competences of authorities of both instances related to issuing decisions concerning public law non-tax liabilities to state; the provisions of the Code of Administrative Proceedings, on the other hand, regulate administrative proceedings, including procedure in specific cases, granting powers of attorney, and issuing decisions (Supreme Administrative Court: II GSK 2374/14). The model of procedure in cases concerning the return of funds allocated for the realization of programmes co-financed by the EU, regulated under the provisions of the Public Finance Act, raises serious doubts as to its consistency with standards of administrative proceedings. The Act not only grants a management institution - a party to a subsidy agreement with competences to inspect the use of funds provided to a beneficiary, but also makes that institution an administrative authority which decides independently whether the subsidy agreement is performed properly. Such a great involvement of the management institution in a subsidy, which enables one entity to examine the same case in administrative proceedings twice, raises justified doubt as to whether a request for re-examining the case settled with a decision issued by a management institution is anything more than a formal appeal measure (Supreme Administrative Court: II GSK 1419/13). 


\section{Essence of "Public Interest" as Condition to Remit a Non-tax Liability to State}

The general clause of "public interest" ensures high flexibility of a legal regulation (Borszowski, 2017: 156; Borszowski, 2013: 47-48). By the doctrine, it is recognized as one of the most important general clauses in Polish legislation, as it is constitutional and is frequently used by the legislator. Most of all, it forms the basis for restricting citizens' rights and freedoms, although it is sometimes a condition to implementing mechanisms for protecting selected values. Therefore, its nature is diverse. The public interest clause introduces multi-aspect relationships between law and social life. Law, in particular, public law, is a result of following a specific policy and a carrier and reflection of values which are socially important. This function is also performed by similar clauses, e.g. "social interest" or "socially justified interest". In the doctrine, those clauses are often treated as interchangeable; however, this is not justified (Żurawik, 2013: 57-69).

The notion of "public interest" as a general clause enables flexible adjustment of a legal regulation resulting from Art. 64/1/2/a of PFA to various situations (Lubelski Voivode: NK.II.0911/241/10). When examining a request for remitting a whole non-tax liability to the state, competent authorities may use the achievements of administrative court case law concerning the meaning of "public interest" (Voivodeship Administrative Court: V SA/Wa 2119/12). As in the case of other general clauses, the notion of "public interest" has not been defined by the legislator. The Public Finance Act does not provide any guidelines or criteria to be used to determine events, situations, or phenomena equaled with public interest either. Therefore, when deciding about a relief in payment of non-tax liabilities to state, consisting in remitting a whole liability, a competent authority should consider the achievements of the judicature and the doctrine and use its own experience derived from previous proceedings concerning such reliefs.

Administrative courts have examined the notion of "public interest" many times. The rulings in that matter are uniform, in principle; however, the emphasis concerning values included in that notion is put on different places. It should be assessed considering values common to the whole society, such as justice, safety, and trust in state authorities (Voivodeship Administrative Court: I SA/Bd 869/13), efficiency of the state apparatus (Voivodeship Administrative Court: I SA/Ke 135/13), and eliminating situations where the payment of a liability will result in encumbering the Treasury with costs of aid. When assessing that notion, one should also consider whether it is justified, in the light of the financial condition of the state, to encumber the state and, what follows, the whole society, with costs of aid provided in that manner. It has been pointed out that it is not an internally 
homogeneous notion and that it consists of a set of generally determined purposes which should be taken into account in the process of applying the law and which should always be referred to the individual situation of the party requesting a relief. It is not possible to define that notion explicitly and, as a result, its meaning may include various aspects of the values referred to above in each individual case (Voivodeship Administrative Court: III SA/Wa 1964/05).

The Constitutional Tribunal has underlined many times that public interest is demonstrated, in particular, in the need to protect the stability of financial interests of the state and maintain the budget balance (Constitutional Tribunal: K 1/12). However, the notion of "public interest" may not be defined too narrowly, e.g. it should not be limited only to "budgetary interest" (Voivodeship Administrative Court: I SA/OI 84/13) or fiscal interest of the state (Voivodeship Administrative Court: V SA/Wa 2614/13), even when a specific liability is a source of budget receipts and it is in public interest that all the obliged parties pay their liabilities to state (Voivodeship Administrative Court: II SA/Bd 727/11). Public interest should be understood not only as a need to ensure the maximum amount of funds on the receipts side of the state budget but also as limiting possible spending e.g. for unemployment benefits or social security (the judgement of the Voivodeship Administrative Court: I SA/Sz 217/13; the judgement of the Supreme Administrative Court: III SA 830/00). There must be no situation where payment of overdue liabilities forces the obliged party, deprived of a possibility to satisfy their essential economic needs, to use state aid (the judgement of the Voivodeship Administrative Court: I SA/Po 595/13; the judgement of the Voivodeship Administrative Court: III $\mathrm{SA} / \mathrm{Ed} \mathrm{496/13).} \mathrm{It} \mathrm{would} \mathrm{not} \mathrm{be} \mathrm{in} \mathrm{the} \mathrm{interest} \mathrm{of} \mathrm{that} \mathrm{citizen} \mathrm{and} \mathrm{neither} \mathrm{would} \mathrm{it}$ be in public interest (the judgment of the Voivodeship Court: I SA/Po 2274/13; the judgment of the Voivodeship Administrative Court: V SA/Wa 2273/10).

\section{Remitting Non-Tax Liabilities to State of Entities Conducting Business Operations}

The public interest as an essential condition for remitting non-tax liability to state of an entity conducting business operations may be applied only with consideration of the regulations under Art. 64/2/5 of PFA. A liability may be remitted only on condition of observing additional standards specified under those provisions (Presnarowicz, 2013: 286). Those standards refer to an obliged entity conducting business operations (regardless from the entity's legal status, organizational and legal form, type of operations and their scale, place of operations, or achieved economic results). That does not mean, however, that if a specific entity conducts business operations, those regulations apply to them in all events. It will be possible 
to apply the regulations only when the entity in question requests for applying a relief in the form of remitting a liability which arose in relation to business operations conducted by that entity. If an obligation of an entity conducting business operations is not related to those operations but to the entity's personal matters, the conditions formulated in Art. 64/2-5 of PFA should not be applied (Voivodeship Administrative Court: I SA/Kr 857/14. At the request of an obliged entity conducting business operations, a competent authority may remit a non-tax liability to state if a relief:

1) is not public aid,

2) is de minimis aid or de minimis aid in agriculture or fishery - within the scope and on the conditions specified indirectly applicable EU legal acts concerning de minimis aid,

3) is public aid:

a) aimed at repairing damage caused by natural disasters or other extraordinary events (separate provisions should specify detailed conditions of providing aid to make it consistent with the principles of the EU common market),

b) aimed at addressing serious economic disturbances (separate provisions should specify detailed conditions of providing aid to make it consistent with the principles of the EU common market),

c) consistent with the principles of the EU common market, specified as acceptable by competent EU authorities, provided for purposes other than listed below (the Council of Ministers may specify, by regulation, the purposes of aid and detailed conditions of granting reliefs, considering the acceptability of providing state aid specified by competent EU authorities).

Therefore, the analysis of the provisions under Art. 64 PFA indicates that entities obliged to pay non-tax liabilities to state, requesting a relief in payment (including in the form of remitting the whole liability), may be divided into two groups. The first group consists of entities which do not conduct business operations; the second group comprises entities which conduct business operations (Kucis-Guściora, 2014: 481). The element common to both groups is the condition of public interest. That condition has to be met for a non-tax liability to the state to be remitted. The difference is that in reference to entities which do not conduct business operations the fact itself that the condition of public interest is met may justify the remittal of a liability. However, if it is an entity conducting business operations that request a relief, even after it has been determined that the condition of public interest is met, it is still necessary to determine whether the application of a relief in payment is acceptable from the viewpoint of standards of public aid for business. 


\section{Conclusions}

The assumed purposes of the work have been achieved, as it has been indicated, based on a detailed analysis of legislation and by identifying dominating trends in administrative courts case law, that the general clause of "public interest" is essential in the procedure of granting reliefs in payment of non-tax liabilities to state. It enables competent authorities to act flexibly and to solve issues of specific obliged entities which expect that form of state aid.

The condition of public interest is one of two conditions specified in Art. 64/1/2/a of PFA. The other condition is the important to interest of the obliged entity, which is also a general clause. Each of those conditions may be an independent basis for applying for a relief in payment of non-tax liabilities to state in the form of payment remittal, subject to meeting the criteria allowing public aid in case of a relief in payment applied with regard to an entity conducting business operations. This conclusion justifies the conjunction "and/or" used by the legislator for joining those conditions in the provision under consideration. In that manner, the interchangeability (disjunctive character) of "public interest" and "important interest of the obliged entity" has been expressed. Those conditions are equal (Dauter, 2002: 48); a competent authority making a decision on remitting a non-tax liability to the state should determine which one prevails and decide to apply for a relief on that basis. Those conditions are not competitive with each other. If it has been determined that at least one of them is met in a specific situation, it means it is not necessary to examine whether the other is met. Meeting one of the conditions may be an independent basis for a positive decision concerning a relief. It may not be assumed that those categories are opposing. A competent authority may determine that the condition of an important interest of a debtor is not met but may notice other expectations expressed by the public interest which make it possible to issue a positive decision concerning the application of a relief in payment (Orłowski, 2001: 87).

The constitutional principle of the state of law results in a balance of individual interest and public interest; public interest restricts a protection of an equitable interest of an individual. Applying discretionary powers with reference to reliefs in payment of non-tax liabilities to state, a competent authority should consider the need of ensuring budget receipts as well as the need to observe the rule of law, citizens' trust to state authorities, and guarantees of social rights and aid provided to people in particularly difficult situations as well as other directives concerning the functioning of the state apparatus (Radzikowski, 2006: 157).

The Public Finance Act does not regulate, in an exhaustive manner, all issues related to applying for reliefs in public law non-tax liabilities to state. Pursuant to 
Art. 67/1 of PFA, the provisions under the Code of Administrative Proceedings of 14 June 1960, the provisions of Chapter III of the Tax Ordinance Act, as applicable, should be applied to all matters concerning those liabilities which are not regulated under the Public Finance Act. The application should consider the systemic and axiological context of the regulations and standards of protecting individuals specified by constitutional principles (Voivodeship Administrative Court: III SA/ $\mathrm{Lu}$ 242/12). Therefore, the provisions of the Code of Administrative Proceedings apply to proceedings concerning public law non-tax liabilities to state, where not regulated by the Public Finance Act, rather than the regulations of Chapter IV of the Tax Ordinance Act (Tax Proceedings) (Dżedzyk, 2012: 3).

\section{References}

Borodo, A.: Glosa do postanowienia NSA z dnia 9 września 2008 r., II GW 4/08 (Commentary on a decision of the Supreme Administrative Court of 9 September 2008, no. II GW 4/08), Orzecznictwo Sądów Polskich (Jurisprudence of Polish Courts) no. 12 (2009).

Borszowski, P.: Określenia nieostre i klauzule generalne jako wyraz elastyczności prawa podatkowego - zarys problematyki (Definitions out of focus and general clauses as an expression of flexibility of tax law - an outline of the issues), Acta Universitatis Wratislaviensis no. 2 (2013).

Borszowski, P.: Określenia nieostre i klauzule generalne w prawie podatkowym (Definitions out of focus and general clauses in tax law), Warszawa: Wolters Kluwer 2017.

Brzezicki, T., Fisz, I.: Należność i opłata roczna za wyłączenie gruntów z produkcji rolnej lub leśnej wymiar i egzekucja (Receivability and annual fee for the exclusion of land from agricultural or forestry production - dimension and enforcement), Casus no. 4 (2013).

Dauter, B.: Nieefektywne sposoby wygasania zobowiązań podatkowych (Inefficient tax liability expiration), Doradztwo Podatkowe (Tax Advisory) no. 6 (2002).

Drwiłło, A.: Inne formy danin niepodatkowych (Other forms of non-tax levies), in: Etel, L. (ed.): System prawa finansowego. Prawo daninowe (Financial Law System. Taxes and Fees), Warszawa: Wolters Kluwer, 2010.

Dżedzyk, J.: W sprawie odpowiedniego stosowania przepisów ordynacji podatkowej oraz przepisów kodeksu postępowania administracyjnego do stosowania ulg w zakresie spłaty zobowiązań publicznoprawnych (On the proper application of the provisions of the Tax Ordinance Act and the provisions of the Administrative Procedure Code for the application of concessions regarding the repayment of public law liabilities), Nowe Zeszyty Samorządowe (New Local Government Notebooks) no. 1 (2012).

Gomułowicz, A., Skoczylas, A.: Prawo podatkowe - aspekt orzeczniczy (Tax law - adjudication), in: Choduń, A., Gomułowicz, A., Skoczylas, A.: Klauzule generalne i zwroty niedookreślone w prawie podatkowym i administracyjnym. Wybrane zagadnienia teoretyczne i orzecznicze (General clauses and phrases that are not specified in tax and administrative law. Selected theoretical and judicial issues), Warszawa: Wolters Kluwer, 2013. 


\section{Public Interest as a Positive Condition of Applying Reliefs in Payment...}

Góreczna, M., Góreczny, G.: Umorzenie należności i opłat rocznych z tytułu wyłączenia gruntów $\mathrm{z}$ produkcji rolnej (Redemption of receivables and annual fees for excluding land from agricultural production), Samorząd Terytorialny (Local Government) no. 9 (2014).

Huchla, A.: Niepodatkowe należności budżetowe w ustawie o finansach publicznych i w ordynacji podatkowej (Non-tax budget receivables in the Public Finance and Tax Law Act), in: Miemiec, W., Sawicka, K. (eds.): Instytucje prawnofinansowe w warunkach kryzysu gospodarczego (Legal funds in the conditions of economic crisis), Warszawa: Wolters Kluwer, 2014.

Jamroży, M., Główka, A.: Korekta deklaracji z tytułu wpłaty z zysku przez jednoosobową spółkę Skarbu Państwa (Correction of declarations from profit for a sole-shareholder company of the State Treasury), Monitor Podatkowy (Tax Review) no. 10 (2017).

Kucia-Guściora, B.: Komentarz do art. 64 (Commentary to art. 64), in: Smoleń, P. (ed.): Ustawa o finansach publicznych. Komentarz (Act on public finance. Comment), Warszawa: C.H. Beck 2014.

Malarewicz-Jakubów, A.: Klauzule generalne i zasady słuszności (General clauses and rules of equity), Białostockie Studia Prawnicze (Bialystok Legal Studies) no. 2 (2014).

Małecki, J.: Refleksje o stosowaniu klauzul generalnych w prawie finansowym (Reflections on the application of general clauses in financial law), in: Zieliński, M.: W kręgu teoretycznych i praktycznych aspektów prawoznawstwa. Księga Jubileuszowa Profesora Bronisława Ziemianina (Within the theoretical and practical aspects of jurisprudence. Book of Jubilee of Professor Bronisław Ziemianin), Poznań: Wydawnictwo Ars boni et aequi, 2005.

Münnich, M.: Zwroty niedookreślone i klauzule generalne w prawie podatkowym. Instrument ochrony praw podatnika czy fundament luzu decyzyjnego organów podatkowych? Wybrane zagadnienia (Undershot phrases and general clauses in tax law. An instrument to protect the taxpayer's rights or the foundations of decision-making decree of tax authorities? Selected issues), in: Wójcicka, E. (ed.): Jednostka wobec władczej ingerencji administracji publicznej (Unit towards imperious interference of public administration), Częstochowa: Wydawnictwo Akademii im. Jana Długosza, 2013.

Ofiarski, Z.: Zasady i przesłanki stosowania z urzędu ulg w zapłacie należności o charakterze cywilnoprawnym przypadających jednostkom samorządu terytorialnego (Rules and conditions for the ex officio use of reliefs in the payment of civil claims due to territorial selfgovernment units), Prace Naukowe Uniwersytetu Ekonomicznego we Wrocławiu (Scientific Works of the University of Economics in Wroclaw) no. 404 (2015).

Orłowski, J.: Przesłanki umorzenia zaległości podatkowych w ordynacji podatkowej (Conditions of extinguishing tax arrears in the Tax Code), Radca Prawny (Legal Counsel) no. 4 (2001).

Popławski, M.: Komentarz do art. 3 (Commentary to art. 3), in: Etel, L. (ed.): Ordynacja podatkowa. Komentarz (Tax Ordinance Act. Comment), Warszawa: Wolters Kluwer, 2017.

Presnarowicz, S.: Komentarz do art. 64 (Comment on art. 64), in: Ruśkowski, E., Salachna, J.M. (eds.): Finanse publiczne. Komentarz praktyczny (Public finances. Practical commentary), Gdańsk: ODDK, 2013.

Radzikowski, K.: Zasady podejmowania i kontroli sądowej decyzji w sprawie umorzenia zaległości podatkowych w świetle uznania administracyjnego (Rules for the taking and judicial review 
of a decision on the cancellation of tax arrears in the light of administrative recognition), Kwartalnik Prawa Publicznego (Quarterly of Public Law) no. 4 (2006).

Strzelec, D.: Kontrola celno-skarbowa dotycząca przestrzegania przepisów prawa podatkowego (Customs and tax control regarding compliance with tax law), Monitor Podatkowy (Fiscal Review) no. 2 (2017).

Ślifirczyk, M.: Niepodatkowe należności budżetowe (Non-tax budget receivables), Gdańskie Studia Prawnicze (Gdańsk Legal Studies) no. 16 (2007).

Wronkowska, S., Zieliński, M.: Problemy i zasady redagowania tekstów prawnych (Problems and rules of editing legal texts), Warszawa: Wydawnictwo Urzędu Rady Ministrów, 1993.

Zieliński, M.: Wykładnia prawa. Zasady, reguły, wskazówki (Interpretation of law. Rules, rules, tips), Warszawa: LexisNexis, 2002.

Żurawik, A.: „Interes publiczny”, „interes społeczny” i ,interes społecznie uzasadniony” (“Public interest", "social interest" and "socially justified interest" An attempt to define concepts), Ruch Prawniczy, Ekonomiczny i Socjologiczny (Legal, Economic and Sociological Movement) no. 2 (2013).

PL: Act of 14 June 1960, Code of Administrative Proceedings, as amended.

PL: Act of 17 June 1966, on Enforcement Proceedings in Administration, as amended.

PL: Act of 3 February 1995, on Protection of Agricultural Lands and Forests, as amended.

PL: Act of 13 October 1995, on Principles of Registration and Identification of Tax Payers and Tax Remitters, as amended.

PL: Act of 20 June 1997, on Road Traffic, as amended.

PL: Act of 28 August 1997, on Employment of Prisoners, as amended.

PL: Tax Ordinance Act of 29 August 1997, as amended.

PL: Public Finance Act of 27 August 2009, as amended.

PL: Act of 16 November 2016, on Polish Fiscal Administration, as amended.

PL: Supreme Administrative Court: I FPS 2/09.

PL: Constitutional Tribunal: K 1/12, OTK-A 2012.

PL: Supreme Administrative Court: III SA 830/00.

PL: Supreme Administrative Court: II GSK 1020/10.

PL: Supreme Administrative Court: II GSK 2084/12.

PL: Supreme Administrative Court: II GSK 1693/13.

PL: Supreme Administrative Court: II GSK 1419/13. 
Public Interest as a Positive Condition of Applying Reliefs in Payment...

PL: Supreme Administrative Court: II GSK 2374/14.

PL: Voivodeship Administrative Court: III SA/Wa 1964/05.

PL: Voivodeship Administrative Court: V SA/Wa 2273/10.

PL: Voivodeship Administrative Court: II SA/Bd 727/11.

PL: Voivodeship Administrative Court: II SA/Łd 117/12.

PL: Voivodeship Administrative Court: III SA/Lu 242/12.

PL: Voivodeship Administrative Court: V SA/Wa 2119/12.

PL: Voivodeship Administrative Court: II SA/Łd 496/13.

PL: Voivodeship Administrative Court: II SA/Ke 135/13

PL: Voivodeship Administrative Court: III SA/Po 535/13.

PL: Voivodeship Administrative Court: I SA/O1 84/13.

PL: Voivodeship Administrative Court: I SA/Sz 217/13.

PL: Voivodeship Administrative Court: I SA/Bd 869/13.

PL: Voivodeship Administrative Court: I SA/Po 595/13.

PL: Voivodeship Administrative Court: III SA/Po 1263/13.

PL: Voivodeship Administrative Court: V SA/Wa 2274/13.

PL: Voivodeship Administrative Court: II SA/Sz 1356/13.

PL: Voivodeship Administrative Court: V SA/Wa 2614/13.

PL: Voivodeship Administrative Court: I SA/Kr 857/14.

PL: Voivodeship Administrative Court: III SA/Kr 574/16.

PL: Lubelski Voivod: no. NK.II.0911/241/10. 